University of Nebraska - Lincoln

DigitalCommons@University of Nebraska - Lincoln

Nebraska Game and Parks Commission -- Staff

Research Publications

Nebraska Game and Parks Commission

$11-2010$

\title{
Match-Mismatch Regulation for Bluegill and Yellow Perch Larvae and Their Prey in Sandhill Lakes
}

Jeffrey C. Jolley

South Dakota State University

David W. Willis

South Dakota State University

Richard S. Holland

Nebraska Game and Parks Commission

Follow this and additional works at: https://digitalcommons.unl.edu/nebgamestaff

Jolley, Jeffrey C.; Willis, David W.; and Holland, Richard S., "Match-Mismatch Regulation for Bluegill and Yellow Perch Larvae and Their Prey in Sandhill Lakes" (2010). Nebraska Game and Parks Commission -Staff Research Publications. 91.

https://digitalcommons.unl.edu/nebgamestaff/91

This Article is brought to you for free and open access by the Nebraska Game and Parks Commission at DigitalCommons@University of Nebraska - Lincoln. It has been accepted for inclusion in Nebraska Game and Parks Commission -- Staff Research Publications by an authorized administrator of DigitalCommons@University of Nebraska - Lincoln. 


\title{
Articles
}

\section{Match-Mismatch Regulation for Bluegill and Yellow Perch Larvae and Their Prey in Sandhill Lakes}

\author{
Jeffrey C. Jolley,* David W. Willis, Richard S. Holland \\ J.C. Jolley, D.W. Willis \\ Department of Wildlife and Fisheries Sciences, South Dakota State University, SNP 138, Box 2140B, Brookings, \\ South Dakota 57007 \\ Present address of J.C. Jolley: U.S. Fish and Wildlife Service, Columbia River Fisheries Program Office, 1211 SE Cardinal \\ Court, Vancouver, Washington 98683
}

\section{R.S. Holland}

Nebraska Game and Parks Commission, P.O. Box 30370, Lincoln, Nebraska 68701

\begin{abstract}
Food availability may regulate fish recruitment, both directly and indirectly. The availability of zooplankton, especially to newly hatched larvae, is thought to be crucial to their early growth and survival. We examined stomach contents of larval bluegill Lepomis macrochirus and yellow perch Perca flavescens in Pelican Lake and Cameron Lake, Nebraska, in 2004 and 2005. We also determined zooplankton availability and calculated prey selection using Chesson's $\alpha$. In addition, we investigated potential match-mismatch regulation of recruitment from 2004 to 2008. Bluegill positively selected copepod nauplii and Bosmina spp., and yellow perch often selected copepods. Abundant zooplankton populations were available for consumption. Matches of both larval bluegill and yellow perch abundance to zooplankton abundance were detected in all years; exact matches were common. Mismatches in predator and prey production were not observed. Predation by age- 0 yellow perch on age-0 bluegill was not observed, even though yellow perch hatched 2 mo prior to bluegill. Given that zooplankton were abundant and well-timed to larval fish relative abundance over the time span of this study, the match-mismatch hypothesis alone may not fully account for observed recruitment variability in these populations. Environmental conditions may also affect recruitment and warrant further investigation.
\end{abstract}

Keywords: Sandhills lakes; Valentine National Wildlife Refuge; predator-prey dynamics; recruitment; phenology; survival; food habits

Received: June 30, 2010; Accepted: August 25, 2010; Published Online Early: August 2010; Published: November 2010 Citation: Jolley JC, Willis DW, Holland RS. 2010. Match-mismatch regulation for bluegill and yellow perch larvae and their prey in Sandhill lakes. Journal of Fish and Wildlife Management 1(2):73-85; e1944-687X. doi: 10.3996/062010JFWM-018

Copyright: All material appearing in the Journal of Fish and Wildlife Management is in the public domain and may be reproduced or copied without permission. Citation of the source, as given above, is requested.

The findings and conclusions in this article are those of the author(s) and do not necessarily represent the views of the U.S. Fish and Wildlife Service.

* Corresponding author: jeffrey_jolley@fws.gov

\section{Introduction}

Recruitment dynamics of populations will ultimately structure fish communities (Diana 1995) and several factors are believed to regulate recruitment, both directly and indirectly. These include abiotic factors such as physical habitat, temperature, and weather (Beard 1982; Jackson and Noble 2000), biotic factors such as food availability and competition (Prout et al. 1990; Welker et al. 1994; Ludsin and DeVries 1997; Bunnell et al. 2003), and predation (Forney 1971; Houde 1987; Rice et al. 1987; Santucci and Wahl 2003). Critical time periods, or bottlenecks, of high mortality may exist for some species (Hjort 1914; May 1974) and researchers commonly incorporate this factor when describing recruitment processes (Marr 1956). This critical period is thought to occur early in age-0 yellow perch Perca flavescens and bluegill Lepomis macrochirus cohort development (Toetz 1966; Forney 1971; Clady 1976; Anderson et al. 1998).

Large annual variation in yellow perch year-class strength is common (Hamley et al. 1983; Henderson 1985) although recruitment patterns may vary among water bodies within a localized region (Lucchesi 1991; Isermann et al. 2007). The early life-stages are commonly 
reported as the time when year-class strength is formed (Clady 1976; Mills and Forney 1981). Variable recruitment is often observed in bluegill populations. Previous research in South Dakota indicated that bluegill recruitment was asynchronous among four small impoundments (Edwards et al. 2007) and the authors suggested that biotic factors likely affected bluegill recruitment. Although bluegill recruitment is generally consistent (i.e., missing year-classes are rare) in Nebraska Sandhill lakes, there appears to be a moderate level of variability in relative year-class strength (Paukert et al. 2002a; Jolley 2009).

The availability of prey when larval fish begin exogenous feeding has been proposed as a potential regulator of recruitment variability (match-mismatch hypothesis; Cushing 1975, 1990). Suitable growth and prey conditions for larval fish are largely determined by the physical environment (e.g., water temperature). Water temperature may indirectly affect larval fish via its influence on the food chain (e.g., zooplankton growth; Sommer et al. 1986; Taylor et al. 1987) in addition to directly mediating spawning and hatching (Beard 1982).

The match-mismatch hypothesis consists of two assumptions: first, that fish at temperate latitudes spawn at approximately the same time each year and, second, that the larvae are released during the spring or autumn peaks in plankton production (Cushing 1990). A match occurs when production of fish larvae and their prey is synchronous or nearly so; conversely, a mismatch occurs when there is a large temporal difference in these two variables (Cushing 1990).

Although the food habits of age- 0 yellow perch have been extensively studied in Midwestern waters (e.g., Weber and Les 1982; Wahl et al. 1993; Fisher and Willis 1997), lake-specific prey-selection patterns in the face of variable prey densities is a topic of importance. Similarly, age-0 bluegill food habits are well-studied (Werner 1969; Mittelbach 1981; Werner and Hall 1988), although data specific to Sandhill lakes have not been collected. Furthermore, the panfish populations of Nebraska Sandhill lakes are high quality (i.e., relatively high abundance of large fish; Paukert et al. 2002b) and relatively unique to the Great Plains. Therefore, examinations of processes that affect recruitment of these populations are of direct interest to managers. The objectives of this study were to 1) describe prey selection for larval and juvenile yellow perch in Cameron and Pelican lakes and bluegill in Pelican Lake, Nebraska, to better understand the prey utilization in these lakes, and 2) examine potential match-mismatch regulation of yellow perch and bluegill recruitment.

\section{Study Area}

Cameron Lake (39 ha) and Pelican Lake (322 ha) are shallow (mean depth $=1.2 \mathrm{~m}$ and $1.3 \mathrm{~m}$, respectively), windswept natural lakes in the Sandhills region of northcentral Nebraska (McCarraher 1977). Submergent and emergent vegetation coverage was low $(<17 \%$ total coverage) in Cameron Lake and was moderate (40-52\% total coverage) in Pelican Lake in 2004 and 2005 (Jolley
2009). The fish communities of both lakes were relatively simple. Cameron Lake contained yellow perch, green sunfish Lepomis cyanellus, black bullhead Ameiurus melas, common carp Cyprinus carpio, fathead minnow Pimephales promelas, and golden shiner Notemigonus crysoleucas. Pelican Lake contained bluegill, largemouth bass Micropterus salmoides, yellow perch, northern pike Esox lucius, black bullhead, common carp, and fathead minnow. The watersheds for both lakes were primarily mixed- and tall-grass prairie and were used for limited livestock grazing (Bleed and Flowerday 1989).

\section{Methods}

We obtained larval yellow perch from Cameron and Pelican lakes and larval bluegill from Pelican Lake using a single 1,000- $\mu \mathrm{m}$-mesh conical ichthyoplankton net (mouth : net length ratio $=1: 3$ ) with a 0.76-m-diameter circular steel frame and $500-\mathrm{mL}$ collection bucket (with 500- $\mu \mathrm{m}$ mesh). Isermann et al. (2002) found no difference in yellow perch density estimates between a 500- and 1,000- $\mu \mathrm{m}$-mesh trawl, although the 1,000- $\mu \mathrm{m}$ size was less likely to become fouled with algae and zooplankton. We sampled larvae approximately every $10 \mathrm{~d}$ from late April to early September in Pelican Lake, 2004-2008 and from late April to mid-June in Cameron Lake, 2004-2005. Randomly chosen, paired locations (i.e., nearshore and offshore) were trawled in Pelican Lake $(n=5)$ and Cameron Lake $(n=4)$ on each occasion. The density of recently hatched (i.e., $<8 \mathrm{~mm}$ ) bluegill and yellow perch larvae in the lakes was indexed using a flowmeter (Ocean Test Equipment, Inc.) in the mouth of the trawl, which allowed determination of water volume towed. We collected zooplankton at the time of each trawling sample during the daytime as two replicates at each site using a 2-mlong tube sampler (Rabeni 1996). Samples were filtered through a $65-\mu \mathrm{m}-\mathrm{mesh}$ net. Replicate samples were collected and processed separately. All samples were preserved in $90 \%$ ethanol and transported to the laboratory for identification and diet analysis.

We tracked the same cohorts by sampling juvenile yellow perch from Cameron Lake in August and juvenile bluegill and yellow perch from Pelican Lake in August or September and the following April or May (age 1) using cloverleaf traps. Each three-lobed cloverleaf trap was constructed of galvanized 6.4-mm-bar mesh, with three 12.7-mm-wide openings between lobes to accommodate entrance of small yellow perch (Brown and St. Sauver 2002). Each lobe was $50 \mathrm{~cm}$ in diameter with a 41$\mathrm{cm}$ height. Collected fishes were preserved in $90 \%$ ethanol and returned to the laboratory. Autumn (age 0) and spring (age 1) juvenile abundance was indexed as the mean number per cloverleaf trap-night.

Year-class strength was assessed in a concurrent study and information from the adult populations was used to examine recruitment; methods are described by Jolley (2009). Adult bluegill (i.e., age 2 and older) and yellow perch (i.e., age 1 and older) were collected annually from each lake using randomly located, overnight sets of double-throated trap (i.e., modified fyke) nets with 
Table 1. Number (No.) and mean total length ( $\mathrm{TL} ; \mathrm{mm}$ ) of yellow perch Perca flavescens and bluegill Lepomis macrochirus examined for food items from Cameron and Pelican lakes, Nebraska, 2004-2005.

\begin{tabular}{|c|c|c|c|c|c|c|c|}
\hline Lake & Date & $\begin{array}{c}\text { No. } \\
\text { (with prey) }\end{array}$ & $\begin{array}{c}\text { No. } \\
\text { examined }\end{array}$ & $\bar{x}$ TL & SE & Range & \% Empty \\
\hline \multicolumn{8}{|l|}{ Cameron } \\
\hline \multicolumn{8}{|c|}{ Yellow perch } \\
\hline \multirow[t]{4}{*}{2004} & 13 May & 30 & 30 & 11.5 & 0.2 & $9.9-13.1$ & 0 \\
\hline & 18 May & 30 & 30 & 12.5 & 0.2 & $9.1-14.9$ & 0 \\
\hline & 27 May & 30 & 30 & 15.7 & 0.5 & $10.0-19.6$ & 0 \\
\hline & 7 June & 30 & 30 & 25.0 & 0.5 & $19.4-30.0$ & 0 \\
\hline \multirow[t]{3}{*}{2005} & 15 May & 18 & 18 & 8.3 & 0.4 & $4.2-12.8$ & 0 \\
\hline & 24 May & 30 & 30 & 14.5 & 0.2 & $12.2-18.3$ & 0 \\
\hline & 2 June & 12 & 12 & 19.0 & 0.6 & $16.0-23.1$ & 0 \\
\hline \multicolumn{8}{|l|}{ Pelican } \\
\hline \multicolumn{8}{|c|}{ Yellow perch } \\
\hline \multirow[t]{12}{*}{2004} & 8 May & 30 & 35 & 8.8 & 0.2 & $6.8-13.8$ & 14 \\
\hline & 17 May & 30 & 30 & 12.7 & 0.2 & $10.4-14.5$ & 0 \\
\hline & 26 May & 30 & 30 & 17.1 & 0.4 & $12.7-20.6$ & 0 \\
\hline & 6 June & 23 & 24 & 23.1 & 0.5 & $18.1-26.9$ & 4 \\
\hline & 16 June & 30 & 31 & 32.2 & 0.7 & $19.5-37.3$ & 3 \\
\hline & 26 June & 17 & 17 & 28.0 & 1.7 & $18.9-39.5$ & 0 \\
\hline & 7 July & 7 & 7 & 31.8 & 2.5 & $22.0-36.8$ & 0 \\
\hline & 17 July & 3 & 3 & 41.8 & 3.7 & $34.6-46.5$ & 0 \\
\hline & 27 July & 9 & 9 & 49.3 & 1.0 & $46.0-53.0$ & 0 \\
\hline & 6 August & 14 & 14 & 57.6 & 2.3 & $40.2-69.5$ & 0 \\
\hline & 16 August & 13 & 13 & 59.8 & 0.9 & $56.2-67.1$ & 0 \\
\hline & 26 August & 9 & 9 & 59.9 & 2.6 & $44.6-74.1$ & 0 \\
\hline 2005 & 3 May & 16 & 16 & 5.4 & 0.1 & $4.2-6.5$ & 100 \\
\hline \multicolumn{8}{|l|}{ Pelican } \\
\hline \multicolumn{8}{|l|}{ Bluegill } \\
\hline \multirow[t]{8}{*}{2004} & 26 June & 3 & 11 & 7.5 & 0.4 & $6.6-11.0$ & 73 \\
\hline & 7 July & 9 & 14 & 9.1 & 0.6 & $6.1-12.4$ & 36 \\
\hline & 17 July & 30 & 47 & 10.8 & 0.4 & $3.8-15.5$ & 36 \\
\hline & 27 July & 30 & 30 & 15.0 & 0.3 & $8.6-18.5$ & 0 \\
\hline & 6 August & 30 & 32 & 15.0 & 0.6 & $7.3-23.3$ & 6 \\
\hline & 16 August & 30 & 30 & 19.1 & 1.0 & $10.9-29.1$ & 0 \\
\hline & 27 August & 30 & 30 & 20.7 & 1.0 & $7.9-29.3$ & 0 \\
\hline & 5 September & 30 & 31 & 19.5 & 1.5 & $11.2-40.1$ & 3 \\
\hline \multirow[t]{6}{*}{2005} & 30 June & 30 & 32 & 8.3 & 0.2 & $7.2-12.3$ & 6 \\
\hline & 11 July & 30 & 31 & 10.7 & 0.4 & $7.8-14.7$ & 3 \\
\hline & 21 July & 30 & 31 & 10.4 & 0.4 & $7.4-14.1$ & 3 \\
\hline & 1 August & 30 & 35 & 11.4 & 0.4 & $8.0-15.6$ & 14 \\
\hline & 11 August & 30 & 30 & 11.2 & 0.4 & $7.3-15.3$ & 0 \\
\hline & 22 August & 30 & 30 & 12.9 & 0.4 & $9.8-18.4$ & 0 \\
\hline
\end{tabular}

16-mm-bar measure mesh, $1.1 \times 1.5-\mathrm{m}$ frames, and $22-\mathrm{m}$ leads. Age was estimated by two independent readers viewing the sagittal otolith in whole view for fish of ages 4 and younger; older fish were aged after cracking and sanding the otoliths. Discrepancies in age estimates were reconciled by reading the otolith in concert. If agreement could not be achieved, the otolith was omitted from the analysis. Mean catch per unit effort values in May or June for age-1 yellow perch and age-2 bluegill were selected as life-stages recruited to the adult population.

Larval fish samples were sorted and identified using identification keys (Auer 1982; Holland-Bartels et al. 1990). Larvae were counted and up to 200 fish per sample were measured ( $\mathrm{mm}$ total length [TL]) from each site. Digestive tracts were removed from up to 30 
Table 2. Percent occurrence and percent by number for zooplankton prey items found in larval yellow perch Perca flavescens stomachs in Cameron Lake, Nebraska, in 2004 and 2005.

\begin{tabular}{|c|c|c|c|c|c|c|c|}
\hline \multirow[b]{2}{*}{ Taxon } & \multicolumn{4}{|c|}{2004} & \multicolumn{3}{|c|}{2005} \\
\hline & 13 May & 18 May & 27 May & 7 June & 15 May & 24 May & 2 June \\
\hline \multicolumn{8}{|l|}{$\%$ Occurrence } \\
\hline Bosminidae & 3.3 & 33.3 & 30.0 & 20.0 & 0 & 3.3 & 16.7 \\
\hline Chydoridae & 6.7 & 20.0 & 26.7 & 66.7 & 0 & 0 & 16.7 \\
\hline Daphnidae & 86.7 & 100.0 & 100.0 & 100.0 & 33.3 & 90.0 & 100.0 \\
\hline Sididae & 0 & 23.3 & 30.0 & 0.0 & 0 & 0 & 0 \\
\hline Copepoda & 100.0 & 96.7 & 66.7 & 60.0 & 94.4 & 100.0 & 91.7 \\
\hline Nauplii & 0 & 0 & 0 & 0 & 0 & 0 & 0 \\
\hline Ostracoda & 0 & 3.3 & 0 & 3.3 & 0 & 0 & 0 \\
\hline Rotifera & 33.3 & 66.7 & 3.3 & 0 & 0 & 0 & 0 \\
\hline \multicolumn{8}{|l|}{$\%$ by number } \\
\hline Bosminidae & 0.2 & 2.3 & 2.5 & 0.3 & 0 & 0.2 & 0.3 \\
\hline Chydoridae & 0.5 & 1.5 & 1.1 & 34.4 & 0 & 0 & 0.5 \\
\hline Daphnidae & 26.8 & 37.5 & 81.7 & 60.2 & 24.4 & 28.8 & 38.6 \\
\hline Sididae & 0 & 1.3 & 2.5 & 0 & 0 & 0 & 0 \\
\hline Copepoda & 61.1 & 33.2 & 12.1 & 5.1 & 75.6 & 71.0 & 60.6 \\
\hline Nauplii & 0 & 0 & 0 & 0 & 0 & 0 & 0 \\
\hline Ostracoda & 0 & 0.2 & 0 & 0.1 & 0 & 0 & 0 \\
\hline Rotifera & 11.3 & 24.1 & 0.1 & 0 & 0 & 0 & 0 \\
\hline
\end{tabular}

randomly selected larvae of each species per sampling occasion during 2004 and 2005 at Cameron and Pelican lakes. Diet items were identified using a microscope, counted, and measured (mm TL). Zooplankton were enumerated and identified to family for common cladocerans (i.e., Bosminidae, Chydoridae, and Daphnidae), and as cyclopoid or calanoid copepods, copepod nauplii (copepodites), ostracods, and rotifers. Each sample was diluted with water to a volume of $30 \mathrm{~mL}$. Three subsamples were then taken with a 5-mL HensenStempel pipette and placed in a Ward counting wheel. Up to 20 individuals of each category were measured and all individuals were counted. The total number of zooplankton of each taxon in a sample was calculated by dividing the number of organisms counted by the proportion of the sample volume processed. Density was then calculated by dividing the number of zooplankton of each taxon by the volume of the water filtered with the tube sampler.

To determine prey selectivity, mean Chesson's (1983) coefficient of selectivity $(\alpha)$ was calculated for individual larval bluegill and yellow perch from each sampling occasion in 2004 and 2005:

$$
\alpha=\frac{r_{i} / n_{i}}{\sum_{i=1}^{m} r_{i} / n_{i}}
$$

where $r_{i}$ is the number of food type $i$ in the predator diet, $n_{i}$ is the number of food type $i$ in the environment, and $m$ is the number of prey types available. Mean $\alpha$ values ( $\pm 95 \% \mathrm{Cl}$ ) were compared with nonselective feeding $(1 / m)$ to determine selectivity. Patterns in prey selection in 2004 and 2005 were examined and used to select prey items included in the match-mismatch analysis.

Temporal predator and prey density curves for yellow perch and bluegill larvae and their prey were constructed for each year and the mean and standard deviation of the peak density was calculated. Prey types used in the analyses were chosen as those showing positive selection by fish during first-feeding (earlier in the season). The width and overlap of the density curves for predator and prey were calculated. Methods outlined by Mertz and Myers (1994) and Johnson (2000) were utilized for this analysis. The following parameters were first calculated:

$$
\begin{aligned}
& t_{0}=\text { timing between peaks of larval production and } \\
& \text { food supply(days); }
\end{aligned}
$$

$\Delta t_{0}=$ annual differences in $\left(t_{0}\right)$ from its mean value;

$\delta=$ one-half width of the density curve for larvae; and $\sigma=$ one-half width of the density curve for zooplankton.

These parameters were used to calculate 1) variability in peak timing from the mean for individual species ( $\sigma$ and $\delta), 2$ ) variability in timing between larval abundance and peak zooplankton production $\left(t_{0}\right)$, and 3 ) year-toyear variability in peak spawning and production $\left(\Delta t_{0}\right)$. When $t_{0}=0$, the match is exact (Mertz and Myers 1994). A mismatch occurs when one-half the width of the larval density curve (i.e., $\delta$ ) does not overlap one-half the width of the zooplankton density curve (i.e., $\sigma$ ). Correlation 


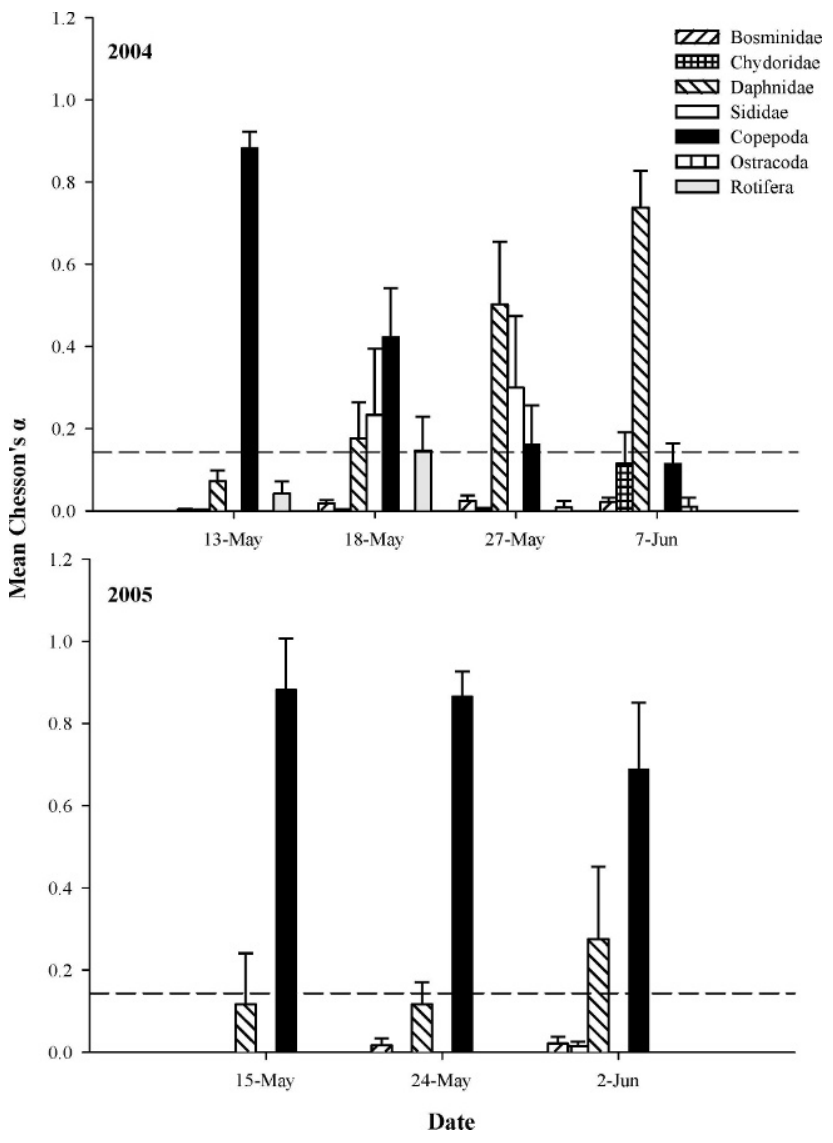

Figure 1. Mean (with $95 \% \mathrm{Cl}$ ) prey selection (Chesson's $\alpha$ ) by yellow perch Perca flavescens in Cameron Lake, Nebraska, 20042005 by prey category of zooplankton. Confidence intervals above the random feeding (dashed) line indicate positive selection, values below the line indicate negative selection, and values overlapping the line indicate neutral selection.

analysis was used to examine the relationship between predator-prey overlap $\left(t_{0}\right)$ and indices of fish recruitment (i.e., larval abundance, juvenile abundance, and adult abundance) for yellow perch and bluegill in Pelican Lake from 2004 to 2008. Yellow perch from Cameron Lake were omitted from this analysis due to inadequate sample size $(N=2 \mathrm{y})$.

\section{Results}

In Cameron Lake, the most abundant zooplankters were daphnids (Supplemental Material, Table S1, http:// dx.doi.org/10.3996/062010-JFWM-018.S1). Chesson's $\alpha>$ 0.125 indicated positive prey selection by yellow perch. Stomachs from 120 yellow perch larvae in May and June of 2004 and 60 stomachs in 2005 were examined for prey items (Table 1; Supplemental Material, Table S2, http:// dx.doi.org/10.3996/062010-JFWM-018.S2). Copepods and daphnids were consistently the most abundant prey item found in stomachs (Table 2). Temporal patterns of negative, neutral, and positive prey selection (Chesson's $\alpha$ $>0.143$ indicated positive prey selection) were found for yellow perch in Cameron Lake (Figure 1) in 2004 and 2005. In 2004, yellow perch selected copepods earliest in the season and later shifted to cladocerans. In 2005, copepods were exclusively positively selected (Figure 1). Empty stomachs were not encountered in either year and copepodites were not observed in stomachs in any year.

In Pelican Lake in 2004, the most abundant zooplankters were generally daphnids, copepods, and copepodites. In 2005, the most abundant zooplankters were generally cladocerans (i.e., daphnids, chydorids, and bosminids). In 2004, 222 yellow perch larvae were examined from May through August for prey items (Table 1). Seven empty stomachs were encountered (3\%). In 2005, 16 larval yellow perch were captured, all with empty stomachs. In 2004, copepods, daphnids, and chydorids were the most abundant prey items found in yellow perch stomachs (Table 3). Yellow perch in Pelican Lake selected copepods earliest, shifted to cladocerans, and later exhibited neutral prey selection for most prey items (Figure 2). Copepodites were not present and rotifers were uncommon in yellow perch stomachs.

Temporal patterns of negative, neutral, and positive prey selection (Chesson's $\alpha>0.143$ indicated positive prey selection) were also found for bluegill in Pelican Lake in 2004 and 2005 (Figure 3). Bluegill larvae had 15\% and 5\% empty stomachs in 2004 and 2005, respectively (Table 1). Bluegill consumed cladocerans, copepods, copepodites, ostracods, and rotifers. Copepodites and Bosmina were common in first-feeding bluegill stomachs while cladocerans and copepods became more common later in the season (Table 4). Copepodites were initially neutrally selected and bluegill eventually preferred cladocerans followed by copepods as prey items. Rotifers and ostracods were consistently neutrally or negatively selected (Figure 3) indicating opportunistic feeding or avoidance of these prey items.

Copepods were elected as an important (i.e., positively selected) prey resource for first-feeding yellow perch in both lakes. The duration of larval yellow perch ( $\mathrm{TL}<$ $13 \mathrm{~mm}$ ) abundance varied from $1 \mathrm{~d}$ in 2005 (Pelican Lake) to $31 \mathrm{~d}$ in 2008 (Pelican Lake). The duration of peak copepod abundance varied from 9 (Cameron Lake, 2005) to $38 \mathrm{~d}$ (Pelican Lake, 2004). The mean annual difference in day of peak abundance for yellow perch larvae and their copepod prey $\left(t_{0}\right)$ was $7.1 \mathrm{~d}$ (Table 5 ). Copepods peaked after yellow perch larvae in three instances and exactly matched in four instances (Figures 4 and 5; Table 5).

Copepodites and Bosmina were important (i.e., positively selected) prey item for first-feeding bluegill and the timing of their combined abundance was examined. The duration of larval bluegill abundance in Pelican Lake ranged from 21 (2004) to $63 \mathrm{~d}$ (2006; Figure 6). The duration of peak copepodites-Bosmina abundance ranged from 42 (2006) to $72 \mathrm{~d}$ (2004). The mean annual difference in peak abundance date for bluegill predators and their prey $\left(t_{0}\right)$ was $14 \mathrm{~d}$. Larval bluegill peaked in abundance before their prey in most years. In 2004, there were two peaks in larval bluegill abundance and zooplankton prey peaked between these two dates (Figure 6; Table 5).

Matches between larval abundance and zooplankton prey occurred in all years (i.e., $\delta$ and $\sigma$ overlapped; Table 5) for both species. There were exact matches (i.e., 
Table 3. Percent occurrence and percent by number for zooplankton prey items found in larval yellow perch Perca flavescens stomachs in Pelican Lake, Nebraska, in 2004.

\begin{tabular}{|c|c|c|c|c|c|c|c|c|c|c|c|c|}
\hline Taxon & $\begin{array}{c}8 \\
\text { May }\end{array}$ & $\begin{array}{c}17 \\
\text { May }\end{array}$ & $\begin{array}{c}26 \\
\text { May }\end{array}$ & $\begin{array}{c}6 \\
\text { June }\end{array}$ & $\begin{array}{c}16 \\
\text { June }\end{array}$ & $\begin{array}{c}26 \\
\text { June }\end{array}$ & $\begin{array}{c}7 \\
\text { July }\end{array}$ & $\begin{array}{c}17 \\
\text { July }\end{array}$ & $\begin{array}{l}27 \\
\text { July }\end{array}$ & $\begin{array}{c}6 \\
\text { August }\end{array}$ & $\begin{array}{c}16 \\
\text { August }\end{array}$ & $\begin{array}{c}26 \\
\text { August }\end{array}$ \\
\hline \multicolumn{13}{|l|}{$\%$ Occurrence } \\
\hline Bosminidae & 0 & 0 & 0 & 0 & 0 & 0 & 14.3 & 33.3 & 37.5 & 57.1 & 100.0 & 77.8 \\
\hline Chydoridae & 0 & 3.3 & 0 & 0 & 50.0 & 64.7 & 71.4 & 66.7 & 75.0 & 50.0 & 100.0 & 77.8 \\
\hline Daphnidae & 0 & 70.0 & 100.0 & 100.0 & 26.7 & 41.2 & 42.9 & 33.3 & 62.5 & 42.9 & 100.0 & 77.8 \\
\hline Sididae & 0 & 0 & 0 & 0 & 0 & 0 & 0 & 0 & 12.5 & 21.4 & 76.9 & 0 \\
\hline Copepoda & 100.0 & 100.0 & 13.3 & 17.4 & 70.0 & 58.8 & 71.4 & 66.7 & 75.0 & 57.1 & 76.9 & 22.2 \\
\hline Nauplii & 0 & 6.7 & 0 & 0 & 0 & 0 & 0 & 0 & 0 & 0 & 0 & 0 \\
\hline Ostracoda & 0 & 0 & 0 & 0 & 50.0 & 47.1 & 14.3 & 0 & 62.5 & 57.1 & 38.5 & 11.1 \\
\hline Rotifera & 0 & 0 & 0 & 0 & 0 & 0 & 0 & 0 & 0 & 0 & 0 & 0 \\
\hline \multicolumn{13}{|l|}{$\%$ by number } \\
\hline Bosminidae & 0 & 0 & 0 & 0 & 0 & 0 & 0.6 & 19.2 & 39.5 & 74.0 & 84.8 & 73.0 \\
\hline Chydoridae & 0 & 0.8 & 0 & 0 & 10.3 & 44.5 & 19.5 & 28.3 & 10.2 & 3.3 & 4.5 & 9.5 \\
\hline Daphnidae & 0 & 15.5 & 97.0 & 98.8 & 2.3 & 33.2 & 18.5 & 12.1 & 31.3 & 14.1 & 9.3 & 16.9 \\
\hline Sididae & 0 & 0 & 0 & 0 & 0 & 0 & 0 & 0 & 0.8 & 1.2 & 0.1 & 0 \\
\hline Copepoda & 100.0 & 83.0 & 3.0 & 1.2 & 50.1 & 15.0 & 60.8 & 40.4 & 16.4 & 6.6 & 1.3 & 0.6 \\
\hline Nauplii & 0 & 0.8 & 0 & 0 & 0 & 0 & 0 & 0 & 0 & 0 & 0 & 0 \\
\hline Ostracoda & 0 & 0 & 0 & 0 & 37.3 & 7.4 & 0.6 & 0 & 1.8 & 0.8 & 0 & 0 \\
\hline Rotifera & 0 & 0 & 0 & 0 & 0 & 0 & 0 & 0 & 0 & 0 & 0 & 0 \\
\hline
\end{tabular}

$\left.t_{0}=0\right)$ in 4 y for yellow perch. No correlations between predator-prey overlap $\left(t_{0}\right)$ and recruitment indices were significant for yellow perch or bluegill ( $P>0.05$; Table 6). For both species the highest observed abundance occurred in a year where the predators temporally matched their prey (Table 5).

\section{Discussion}

Larval fish predators and their zooplankton prey were temporally well-matched in our study. Prey densities were adequate for larval yellow perch and bluegill. Although a low number of yellow perch were detected in

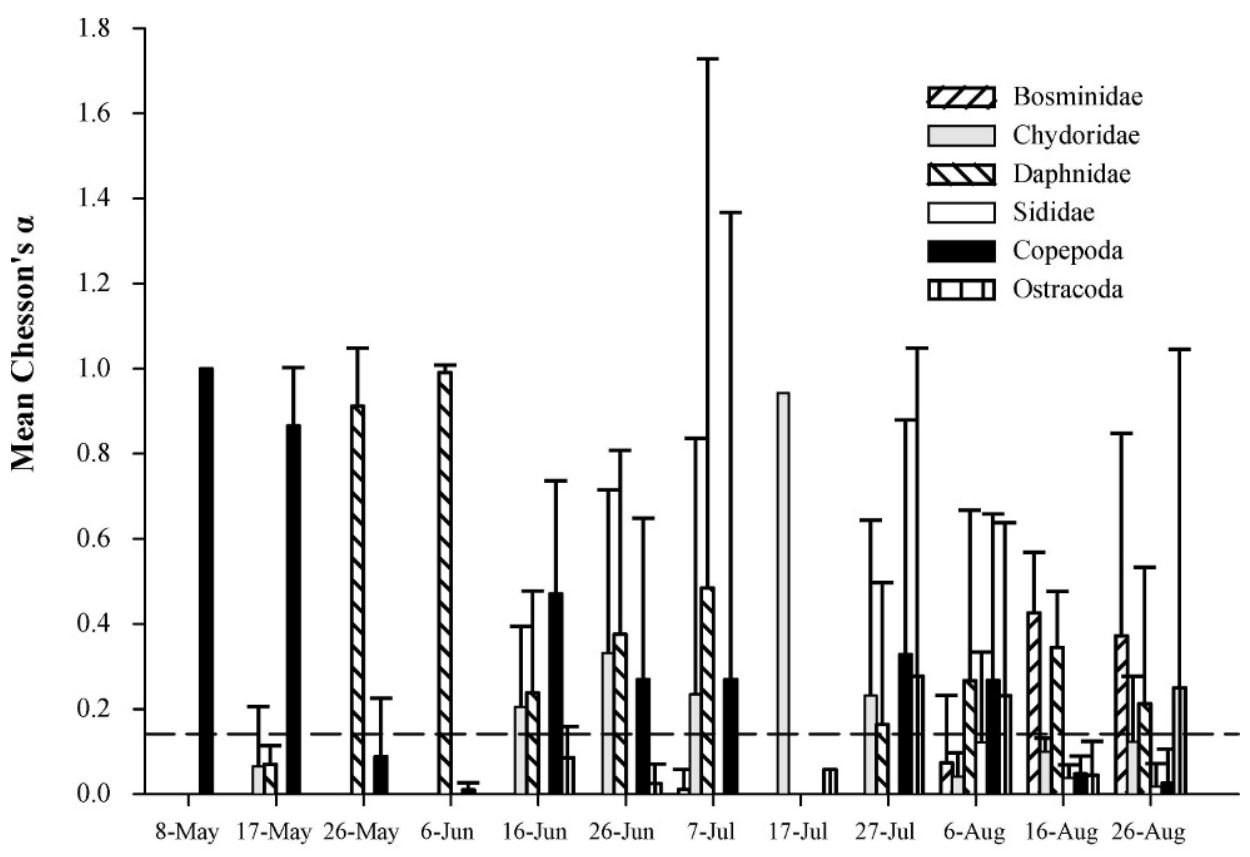

Date

Figure 2. Mean (with $95 \% \mathrm{Cl}$ ) prey selection (Chesson's $\alpha$ ) by yellow perch Perca flavescens in Pelican Lake, Nebraska, 2004 by prey category of zooplankton. Confidence intervals above the random feeding (dashed) line indicate positive selection, values below the line indicate negative selection, and values overlapping the line indicate neutral selection. 


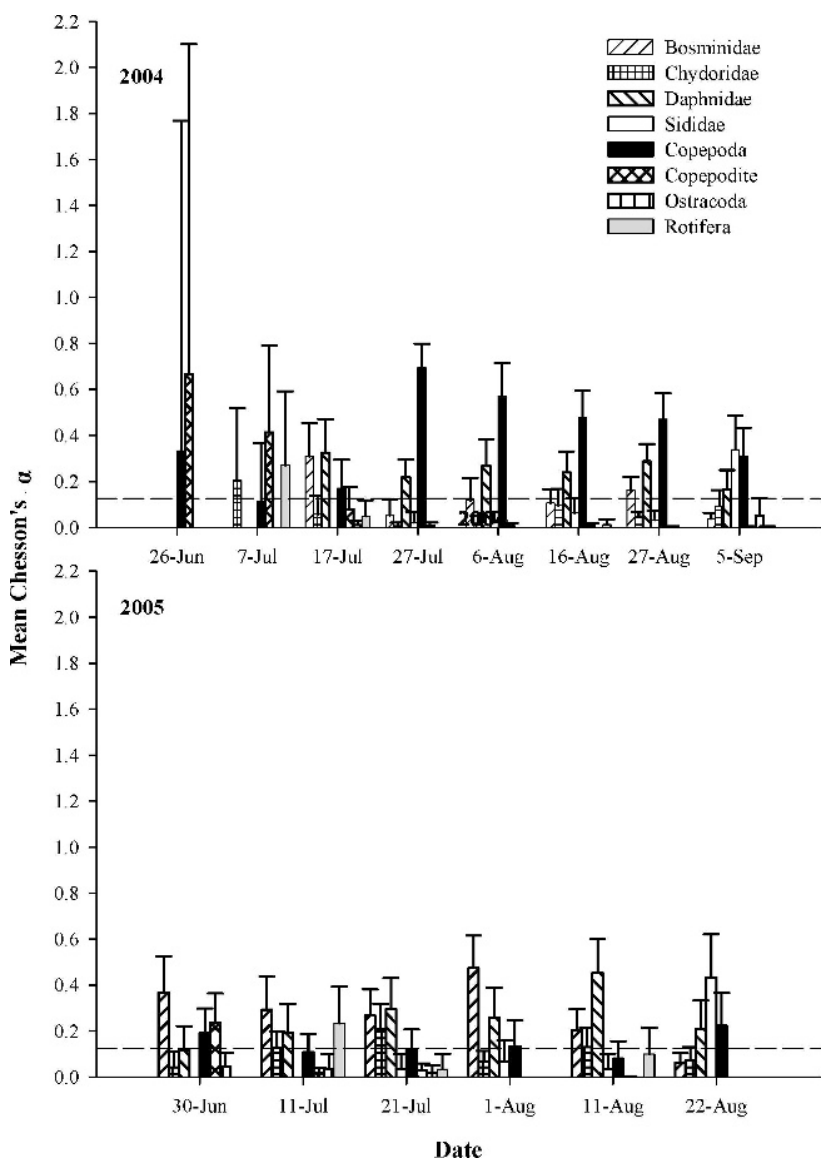

Figure 3. Mean (with $95 \% \mathrm{Cl}$ ) prey selection (Chesson's $\alpha$ ) by bluegill Lepomis macrochirus in Pelican Lake, Nebraska, 2004 and 2005 by prey category of zooplankton. Confidence intervals above the random feeding (dashed) line indicate positive selection, values below the line indicate negative selection, and values overlapping the line indicate neutral selection.

both lakes in 2005, prey was seemingly available for consumption. The observation of all larval yellow perch collected with empty stomachs in 2005 in Pelican Lake was notable. It is unknown if these fish were in a stressed condition upon their collection and were unable to adequately seek prey items or if they may not have started first-feeding (yolk-sacs were not present). Sparse prey resources for first-feeding fish larvae have been commonly implicated as a cause of high mortality (May 1974; Cushing 1975, 1990; Hart and Werner 1987) and Toetz (1966) experimentally reported mass starvation of larval bluegill between 5 and $6 \mathrm{~mm} \mathrm{TL}$, which corresponded to initiation of exogenous feeding. Isermann and Willis (2008) suggested that factors prior to, during, or immediately following hatching may play a critical role in the recruitment of yellow perch under the constraint of a narrow spawning window. Our results are contrary to multiple experimental studies in which survival of larval fishes is most influenced by zooplankton biomass (Hart and Werner 1987; Welker et al. 1994). Conversely, Houde (1994) predicted that starvation of larval fishes in freshwater environments was less likely to occur than in marine environments because freshwater fish larvae are generally larger, thus conferring greater energy reserves and resistance to starvation (Miller et al. 1988). Previous research examining the relation of zooplankton biomass and abundance to larval growth and survival of panfish has had mixed results (Pope and Willis 1998; Garvey et al. 2002; Bunnell et al. 2003).

In 2005, yellow perch hatched over a very narrow time frame in Pelican Lake (4 d) and larvae were only collected in low numbers on one day, likely indicating a relatively weak initial year-class. Concurrently, Pelican Lake experienced a drop in water temperature from nearly $17^{\circ} \mathrm{C}$ to nearly $6^{\circ} \mathrm{C}$ over a period of $2 \mathrm{wk}$ in late April (Jolley 2009). This corresponded to the time period when yellow perch eggs would have been incubating and hatching. It is unclear whether the eggs or newly hatched larvae were negatively affected by this cold front. Jansen et al. (2009) simulated the effect of a cold front on yellow perch eggs and found no decrease in egg survival, suggesting that the newly hatched larval stage may be more susceptible than eggs to these extreme weather events. Sandhill lakes are shallow and windswept; they, thus, are susceptible to erratic temperature changes and can warm and cool quickly. Jolley (2009) examined the relation of recruitment (i.e., year-class strength) of bluegill and yellow perch to climatic variables in several Sandhill lakes and found asynchronous recruitment among the study lakes. In addition, limited support for the concept of climatic influence on bluegill and yellow perch was found over the years examined.

No mismatches in predator and prey abundance were detected over the years examined in our study; thus, we cannot determine if severe mismatches in the appearance of fish larvae and their zooplankton prey would lead to depressed survival of age-0 bluegill and yellow perch in Nebraska Sandhill lakes. Density of larval fish and zooplankton was variable among years but exact matches occurred frequently for bluegill and yellow perch. Although zooplankton density can vary spatially (Young et al. 2009) leading to potential spatial mismatches (Chick and Van Den Avyle 1999), differences in zooplankton densities between inshore and offshore strata were not apparent (Jolley 2009). Intrastation variability of zooplankton density was generally less than interstation variability, and density differences were rarely detected among regions of the lake (unpublished data). Young et al. (2009) reported that small-scale patchiness (i.e., $<1 \mathrm{~m}$ ) accounted for the majority of the variation in zooplankton abundance, which could contribute to spatial mismatches considering the small search volume reported for many larval fish species ( 2.5 L; Blaxter 1986; Pepin 2004). They suggested that measures of average prey density made over larger scales may be independent of the feeding of individuals. Determination of the scale of zooplankton patchiness was beyond the scope of our study but may be a topic worth revisiting in future studies.

Although copepodites and rotifers have also been reported (Whiteside et al. 1985; Schael et al. 1991; Wahl et al. 1993; Fisher and Willis 1997) as a preferred prey item of newly hatched yellow perch, we found rare 
Table 4. Percent occurrence and percent by number for zooplankton prey items found in larval bluegill Lepomis macrochirus stomachs in Pelican Lake, Nebraska, in 2004-2005.

\begin{tabular}{|c|c|c|c|c|c|c|c|c|c|c|c|c|c|c|}
\hline \multirow[b]{2}{*}{ Taxon } & \multicolumn{7}{|c|}{2004} & \multicolumn{7}{|c|}{2005} \\
\hline & $\begin{array}{c}26 \\
\text { June }\end{array}$ & $\begin{array}{c}7 \\
\text { July }\end{array}$ & $\begin{array}{c}17 \\
\text { July }\end{array}$ & $\begin{array}{l}27 \\
\text { July }\end{array}$ & $\begin{array}{c}6 \\
\text { August }\end{array}$ & $\begin{array}{c}16 \\
\text { August }\end{array}$ & $\begin{array}{c}27 \\
\text { August }\end{array}$ & $\begin{array}{c}5 \\
\text { Sept }\end{array}$ & $\begin{array}{c}30 \\
\text { June }\end{array}$ & $\begin{array}{c}11 \\
\text { July }\end{array}$ & $\begin{array}{l}21 \\
\text { July }\end{array}$ & $\begin{array}{c}1 \\
\text { August }\end{array}$ & $\begin{array}{c}11 \\
\text { August }\end{array}$ & $\begin{array}{c}22 \\
\text { August }\end{array}$ \\
\hline \multicolumn{15}{|l|}{$\%$ Occurrence } \\
\hline Bosminidae & 0 & 0 & 63.3 & 50.0 & 80.0 & 83.3 & 96.7 & 83.3 & 46.7 & 60.0 & 60.0 & 76.7 & 63.3 & 70.0 \\
\hline Chydoridae & 0 & 22.2 & 10.0 & 3.3 & 6.7 & 40.0 & 53.3 & 60.0 & 6.7 & 56.7 & 63.3 & 33.3 & 40.0 & 50.0 \\
\hline Daphnidae & 0 & 0 & 46.7 & 83.3 & 60.0 & 83.3 & 96.7 & 80.0 & 26.7 & 63.3 & 76.7 & 60.0 & 96.7 & 83.3 \\
\hline Sididae & 0 & 0 & 0 & 3.3 & 3.3 & 13.3 & 10.0 & 43.3 & 0 & 0.0 & 3.3 & 6.7 & 3.3 & 43.3 \\
\hline Copepoda & 33.3 & 11.1 & 30.0 & 96.7 & 76.7 & 83.3 & 86.7 & 90.0 & 60.0 & 33.3 & 36.7 & 20.0 & 23.3 & 63.3 \\
\hline Nauplii & 66.7 & 44.4 & 10.0 & 3.3 & 3.3 & 10.0 & 6.7 & 6.7 & 40.0 & 6.7 & 16.7 & 0 & 3.3 & 0 \\
\hline Ostracoda & 0 & 0 & 3.3 & 0 & 0 & 0 & 0 & 6.7 & 10.0 & 6.7 & 3.3 & 0 & 0 & 0 \\
\hline Rotifera & 0 & 66.7 & 16.7 & 0 & 0 & 3.3 & 0 & 3.3 & 0 & 20.0 & 0 & 0 & 10.0 & 0 \\
\hline \multicolumn{15}{|l|}{$\%$ by number } \\
\hline Bosminidae & 0 & 0 & 46.7 & 15.3 & 42.6 & 46.2 & 47.9 & 34.6 & 21.7 & 28.3 & 32.9 & 51.2 & 44.5 & 32.8 \\
\hline Chydoridae & 0 & 8.8 & 3.5 & 0.2 & 0.5 & 9.3 & 5.3 & 19.2 & 1.6 & 22.7 & 23.9 & 5.7 & 14.6 & 12.9 \\
\hline Daphnidae & 0 & 0 & 38.1 & 21.9 & 22.7 & 12.9 & 18.4 & 23.4 & 10.1 & 34.0 & 31.2 & 39.2 & 33.0 & 28.9 \\
\hline Sididae & 0 & 0 & 0 & 0.2 & 0.2 & 0.7 & 0.2 & 3.2 & 0 & 0 & 0.4 & 1.0 & 0.2 & 3.6 \\
\hline Copepoda & 10.0 & 5.9 & 5.4 & 61.9 & 33.6 & 30.4 & 28.0 & 19.0 & 34.1 & 11.5 & 9.0 & 2.9 & 6.4 & 21.8 \\
\hline Nauplii & 90.0 & 20.6 & 1.6 & 0.4 & 0.5 & 0.3 & 0.2 & 0.4 & 27.9 & 0.4 & 2.1 & 0 & 0.2 & 0 \\
\hline Ostracoda & 0 & 0 & 0.4 & 0 & 0 & 0 & 0 & 0.2 & 4.7 & 0.7 & 0.4 & 0 & 0 & 0 \\
\hline Rotifera & 0 & 64.7 & 4.3 & 0 & 0 & 0.1 & 0 & 0.1 & 0 & 2.4 & 0 & 0 & 1.1 & 0 \\
\hline
\end{tabular}

consumption of these taxa despite their availability. Increased predation on daphnids by larger (i.e., $30 \mathrm{~mm}$ ) yellow perch has been previously reported (Whiteside et al. 1985; Prout et al. 1990) and positive selection for these diet items has been shown (Mills et al. 1984; Schael et al. 1991). Our observations corroborate such findings although daphnids were first consumed when yellow perch were between 15 and $17 \mathrm{~mm}$ TL and Wahl et al. (1993) reported consumption of daphnids by larval yellow perch as small as $9 \mathrm{~mm}$ TL.

Yellow perch hatched 2 mo before bluegill and had the potential to either prey upon or compete with

Table 5. Mean peak larval abundance $\left(n / 100 \mathrm{~m}^{3}\right)$, parameters used in match-mismatch examination, and result for yellow perch Perca flavescens and copepods in Cameron and Pelican Lake, Nebraska, and for bluegill Lepomis macrochirus and combined copepodite-Bosmina in Pelican Lake, Nebraska, 2004-2008. Parameters are $t_{0}$ (timing between peaks of larval production and food supply in days), $\Delta t_{0}$ (annual differences in $\left[t_{0}\right]$ from its mean value), $\delta$ (one-half width of the production period for larvae), and $\sigma$ (one-half width of the production period for zooplankton).

\begin{tabular}{|c|c|c|c|c|c|c|c|c|}
\hline \multirow[b]{2}{*}{ Lake } & \multirow{2}{*}{$\begin{array}{l}\text { Predator-prey } \\
\text { combination }\end{array}$} & \multirow[b]{2}{*}{ Year } & \multirow{2}{*}{$\begin{array}{l}\text { Peak larval } \\
\text { abundance }\end{array}$} & \multicolumn{4}{|c|}{ Parameter } & \multirow[b]{2}{*}{ Result } \\
\hline & & & & $t_{0}$ & $\Delta t_{0}$ & $\delta$ & $\sigma$ & \\
\hline \multirow[t]{2}{*}{ Cameron } & Yellow perch-copepods & 2004 & 804 & 19 & 11.9 & 9.5 & 7 & Match \\
\hline & & 2005 & 2 & 0 & 7.1 & 0 & 4.5 & Exact match \\
\hline \multirow[t]{11}{*}{ Pelican } & Yellow perch-copepods & 2004 & 23 & 0 & 7.1 & 0 & 19 & Exact match \\
\hline & & 2005 & 6 & 0 & 7.1 & 0 & 10 & Exact match \\
\hline & & 2006 & 46 & 21 & 13.9 & 4.5 & 16 & Weak match \\
\hline & & 2007 & 89 & 0 & 7.1 & 4 & 9 & Exact match \\
\hline & & 2008 & 238 & 10 & 2.9 & 15.5 & 26 & Match \\
\hline & Bluegill-copepodite-Bosmina & $2004^{\mathrm{a}}$ & 66 & 20 & 8.0 & 20.5 & 36 & Match \\
\hline & & $2004^{b}$ & 57 & 9 & 3.0 & 10.5 & 36 & Match \\
\hline & & 2005 & 169 & 21 & 9.0 & 21 & 26.5 & Match \\
\hline & & 2006 & 315 & 10 & 2.0 & 31.5 & 21 & Match \\
\hline & & 2007 & 377 & 11 & 1.0 & 21 & 26 & Match \\
\hline & & 2008 & 1,269 & 11 & 1.0 & 19 & 25 & Match \\
\hline
\end{tabular}

\footnotetext{
${ }^{a}$ First peak in larval bluegill abundance in 2004.

${ }^{b}$ Second peak in larval bluegill abundance in 2004.
} 


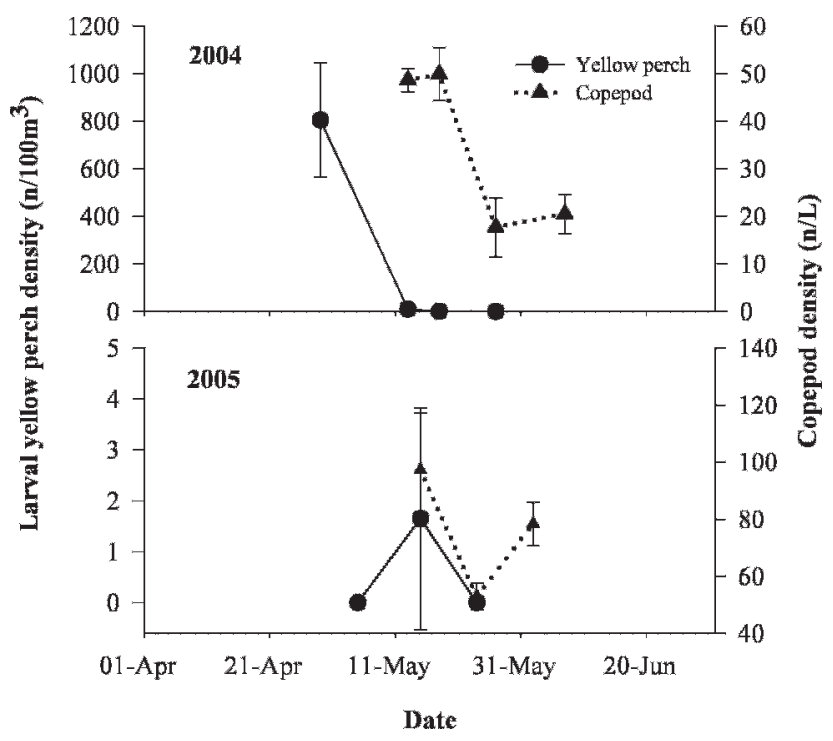

Figure 4. Larval yellow perch Perca flavescens density (solid line) and copepod density (broken line) in Cameron Lake, Nebraska, in 2004 and 2005 ( $n=$ number).

bluegill larvae. We did not observe any larval bluegill consumed by juvenile yellow perch in this study (up to $74 \mathrm{~mm} \mathrm{TL}$ ). Although Graeb et al. (2006) demonstrated experimentally that yellow perch begin a shift to fish prey at $80 \mathrm{~mm} \mathrm{TL}$, most field studies do not report consistent piscivory by yellow perch until they attain 130-150 mm TL (Clady 1974; Keast 1985; Fullhart et al. 2002), a larger size than examined in our study.

Total zooplankton densities in 2004 were low on the first day that bluegill larvae were collected, which may explain the lack of positive prey selection for any particular group of zooplankton by newly hatched bluegill larvae in 2004. Partridge and DeVries (1999) noted a high proportion of rotifers in larval bluegill diets, which may lead to suboptimal bluegill growth. Rotifers were rarely consumed in our study, although they were remarkably abundant in Pelican Lake in 2004. The availability of energetically profitable prey (i.e., copepods and cladocerans) likely precluded bluegill larvae from consuming rotifers.

Although densities of yellow perch larvae varied considerably ( $>300 \%$ ) among years, it appears that recruitment of yellow perch was relatively consistent in Pelican and Cameron lakes over the years examined and the observed densities of larval yellow perch were generally higher than reported values of density in six South Dakota glacial lakes monitored for over 8 y (Jansen 2008). Many other Sandhill lakes concurrently studied exhibited relatively consistent recruitment (Jolley 2009).

The life history and reproductive and spawning behavior of many species have evolved in ecosystems where environmental variability is unpredictable (Winemiller and Rose 1993). A combination of trophodynamic and physical factors may interact in complex ways, over multiple temporal and spatial scales, to affect larval fish survival, growth, and recruitment (Fitzgerald et al. 2001; Houde 2008). Availability of appropriate prey in time

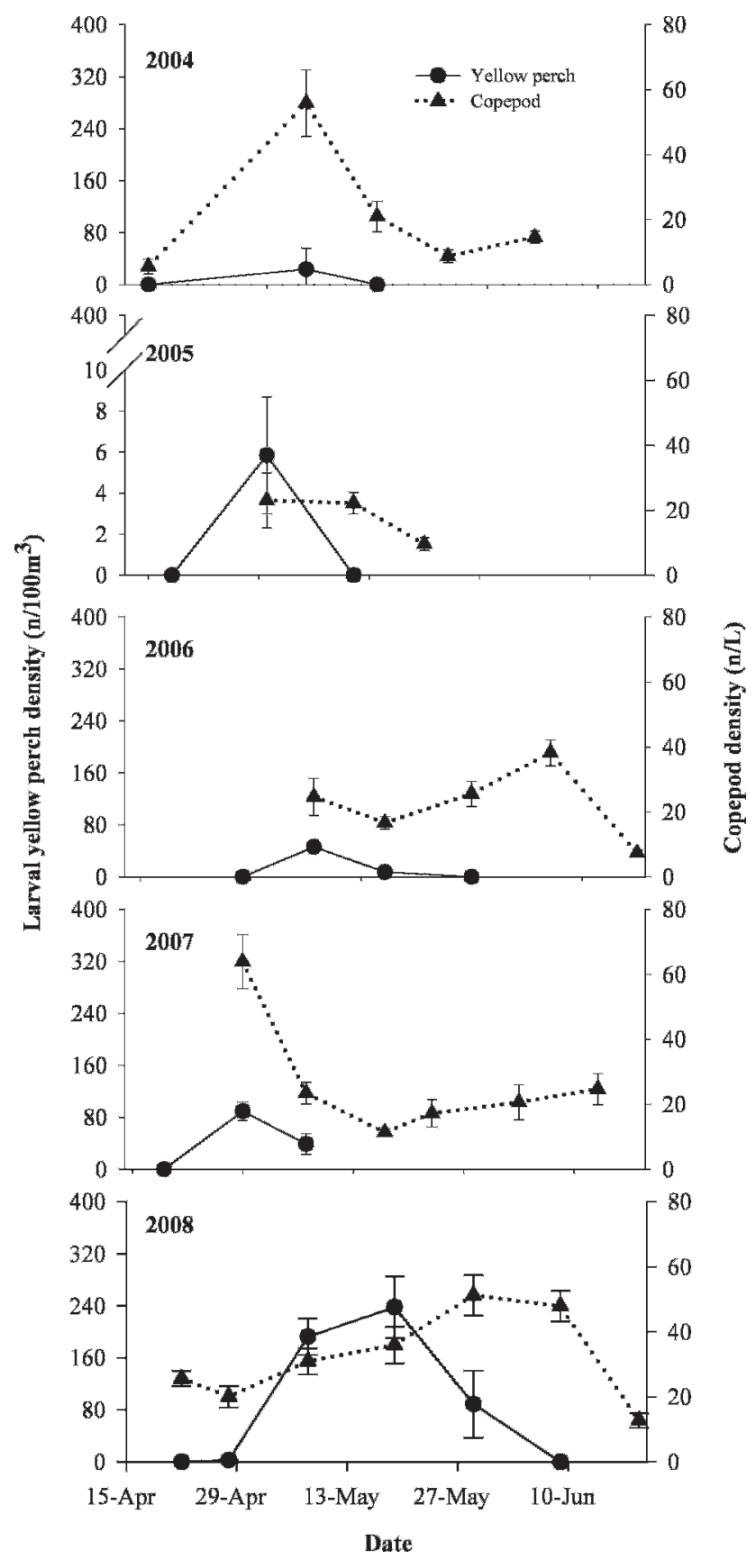

Figure 5. Larval yellow perch Perca flavescens density (solid line) and copepod density (broken line) in Pelican Lake, Nebraska, 2004-2008 ( $\mathrm{n}=$ number).

and space is no doubt an important factor to the survival and recruitment of age- 0 fish and is likely a component of an integrated process acting throughout early life-stages to explain components of recruitment variability (Houde 2008). Many studies that provide support for the match-mismatch hypothesis involved marine species and systems (Cushing 1990; Fortier and Gagné 1990; Gotceitas et al. 1996; Johnson 2000); it is lesser studied in freshwater systems, with some support for landlocked striped bass Morone saxatilis (Chick and Van Den Avyle 1999), threadfin shad Dorosoma pete- 


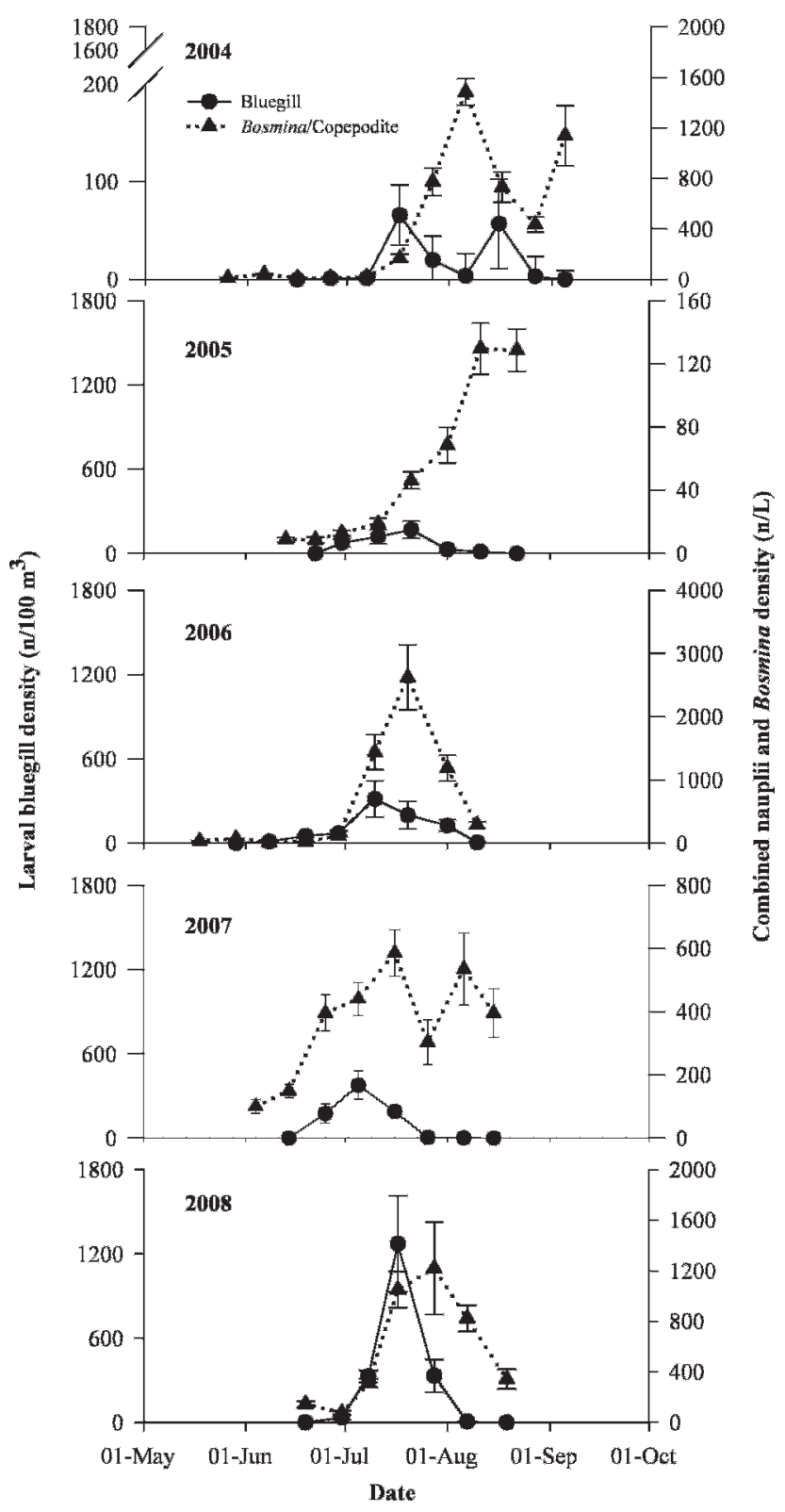

Figure 6. Larval bluegill Lepomis macrochirus density (solid line) and combined copepodite and Bosmina density (broken line) in Pelican Lake, Nebraska, 2004-2008 ( $\mathrm{n}=$ number).

nense (Betsill and Van Den Avyle 1997) and yellow perch (Fitzgerald et al. 2001). Houde (1994) found that marine larvae (compared to freshwater) may be more susceptible to starvation mortality due to high metabolic demand and small size at hatch. These traits may be related to the applicability of the match-mismatch hypothesis for marine fishes. Houde (1994) found that freshwater fish larvae may be more susceptible to episodic mortalities that affect recruitment, but that the juvenile stage may be equally important in regulating and controlling recruitment. In light of these complexities, and given that zooplankton were abundant and well-timed to larval fish abundance over the initial years of this study, the match-mismatch hypothesis may not
Table 6. Bivariate correlations between predator-prey overlap $\left(t_{0}\right)$ and fish abundance indices for yellow perch Perca flavescens and bluegill Lepomis macrochirus. Abundance indices are peak larval abundance (mean $n / \mathrm{m}^{3}$ ), autumn and spring juvenile catch per unit effort (CPUE; mean $n /$ cloverleaf trap-night), and age- 1 and age-2 CPUE (mean $n /$ trap-net night). Number of data pairs $(N)$, correlation coefficient $(r)$, and $P$-value are given for each bivariate correlation.

\begin{tabular}{lrrrrrrrr}
\hline \multirow{2}{*}{$\begin{array}{l}\text { Independent } \\
\text { variable }\end{array}$} & \multicolumn{3}{c}{ Yellow perch } & & \multicolumn{3}{c}{ Bluegill } \\
\cline { 2 - 3 } \cline { 7 - 8 } & $\boldsymbol{N}$ & $\boldsymbol{r}$ & $\boldsymbol{P}$ & & $\boldsymbol{N}$ & $\boldsymbol{r}$ & $\boldsymbol{P}$ \\
\hline Peak larval abundance & 7 & -0.19 & 0.68 & & 6 & -0.34 & 0.51 \\
\hline Autumn juvenile CPUE & 7 & 0.13 & 0.77 & & 6 & 0.08 & 0.88 \\
Spring juvenile CPUE & 7 & 0.32 & 0.48 & & 6 & -0.36 & 0.49 \\
Age 1 CPUE & 7 & -0.51 & 0.38 & & & \\
Age 2 CPUE & & & & 5 & -0.43 & 0.47 \\
\hline
\end{tabular}

be able to account for observed recruitment variability in the populations that we studied.

Given the importance of copepods, copepodites, daphnids, and bosminids as prey for larval yellow perch and bluegill, more in-depth examination of these relationships is warranted. Abundance indices of these zooplankton taxa may be used as surrogates for prey availability. In addition, the dynamic nature of zooplankton populations may suggest important consequences via timing (e.g., match-mismatch regulation; Cushing 1975, 1990), which could be further explored. Our sampling interval of $10 \mathrm{~d}$ may lack the required resolution to fully understand the relation between zooplankton and larval bluegill and yellow perch recruitment. If catastrophic mortality events happen in a short time (Hjort 1914; May 1974) then more frequent sampling may be required to pinpoint the timing and explanation for it. Multiple life-stage abundance indices of yellow perch and bluegill were not correlated to zooplankton abundance indices, although those results were based on a low number of observations (Jolley 2009). Continued stage-specific investigations of the relationship of zooplankton to larval fish growth and recruitment may produce important insights into the dynamics of bluegill and yellow perch in temperate lakes. In addition, examination of later life-stages (e.g., juveniles) of bluegill and yellow perch likely is also necessary. Studies that incorporate multiple life-stages (Ludsin and DeVries 1997; Jolley 2009) and include ecosystem processes are especially valuable (Cury et al. 2008).

\section{Supplemental Material}

Please note: The Journal of Fish and Wildlife Management is not responsible for the content or functionality of any supplemental material. Queries should be directed to the corresponding author.

Table S1. Zooplankton availability.

Found at DOI: 10.3996/062010-JFWM-018.S1 (292 KB XLS).

Table S2. Larval fish diets.

Found at DOI: 10.3996/062010-JFWM-018.S2 (1757 KB $\mathrm{XLS})$. 


\section{Acknowledgments}

We thank A. Husman, E. Lorenzen, J. Rydell, D. Coulter, W. Bauer, and C. Longhenry for field and laboratory assistance. M. Lindvall and Valentine National Wildlife Refuge provided access to Pelican Lake and R. Lackaff provided access to Cameron Lake. We thank D. Graham, D. Hartmann, D. Kruger, and the Valentine State Fish Hatchery for assistance. We also thank the three anonymous reviewers and the Subject Editor for valuable improvement to this manuscript. Funding for this project was provided by the Nebraska Game and Parks Commission through Federal Aid in Sport Fish Restoration Project F-118-R.

\section{References}

Anderson MR, Fisher SJ, Willis DW. 1998. Relationship between larval and juvenile perch abundance in eastern South Dakota glacial lakes. North American Journal of Fisheries Management 18:989-991.

Auer NA. 1982. Identification of larval fishes of the Great Lakes basin with emphasis on the Lake Michigan drainage. Ann Arbor, Michigan: Great Lakes Fishery Commission.

Beard TD. 1982. Population dynamics of young-of-theyear bluegill. Madison, Wisconsin: Wisconsin Department of Natural Resources. Technical Bulletin 127.

Betsill RK, Van Den Avyle MJ. 1997. Effect of temperature and zooplankton abundance on growth and survival of larval threadfin shad. Transactions of the American Fisheries Society 126:999-1011.

Blaxter JHS. 1986. Development of sense organs and behavior of teleost larvae with special reference to feeding and predator avoidance. Transactions of the American Fisheries Society 115:98-114.

Bleed A, Flowerday C. 1989. Introduction. Pages 1-15 in Bleed A, Flowerday C, editors. An atlas of the Sand Hills. Lincoln: University of Nebraska.

Brown ML, St. Sauver T. 2002. An assessment of yellow perch, Perca flavescens, stocking contributions in eastern South Dakota lakes. Fisheries Management and Ecology 9:225-234.

Bunnell DB, González MJ, Stein RA. 2003. Zooplankton biomass enhances growth, but not survival, of firstfeeding Pomoxis spp. larvae. Canadian Journal of Fisheries and Aquatic Sciences 60:1314-1323.

Chesson J. 1983. The estimation and analysis of preference and its relationship to foraging models. Ecology 70:1227-1235.

Chick JH, Van Den Avyle MJ. 1999. Zooplankton variability and larval striped bass foraging: evaluating potential match-mismatch regulation. Ecological Applications 9:320-334.

Clady MD. 1974. Food habits of yellow perch, smallmouth bass and largemouth bass in two unproductive lakes in northern Michigan. American Midland Naturalist 91:453-459.

Clady MD. 1976. Influence of temperature and wind on the survival of early stages of yellow perch, Perca flavescens. Journal of the Fisheries Research Board of Canada 33:1887-1893.

Cury PM, Shin Y-J, Planque B, Durant JM, Fromentin J-M, Kramer-Schadt S, Stenseth NC, Travers M, Grimm V. 2008. Ecosystem oceanography for global change in fisheries. Trends in Ecology and Evolution 23:338-346.

Cushing DH. 1975. Marine ecology and fisheries. United Kingdom: Cambridge University Press.

Cushing DH. 1990. Plankton production and year-class strength in fish populations: an update of the match/ mismatch hypothesis. Advances in Marine Biology 26: 249-293.

Diana JS. 1995. Biology and ecology of fishes. Carmel, Indiana: Cooper.

Edwards KE, Phelps QE, Graeb BDS, Willis DW. 2007. Asynchronous bluegill recruitment in four South Dakota impoundments. Journal of Freshwater Ecology 22:19-22.

Fisher SJ, Willis DW. 1997. Early life history of yellow perch in two South Dakota glacial lakes. Journal of Freshwater Ecology 12:421-429.

Fitzgerald DG, Dale AR, Thomas MV, Sale PF. 2001. Application of otolith analyses to investigate broad size distributions of young yellow perch in temperate lakes. Journal of Fish Biology 58:248-263.

Forney JL. 1971. Development of dominant year classes in a yellow perch population. Transactions of the American Fisheries Society 100:739-749.

Fortier L, Gagné JA. 1990. Larval herring (Clupea harengus) dispersion, growth, and survival in the St. Lawrence Estuary: match/mismatch or membership/ vagrancy? Canadian Journal of Fisheries and Aquatic Sciences 47:1898-1912.

Fullhart HG, Parsons BG, Willis DW, Reed JR. 2002. Yellow perch piscivory and its possible role in structuring littoral zone fish communities in small Minnesota Lakes. Journal of Freshwater Ecology 17:37-43.

Garvey JE, Herra TP, Leggett WC. 2002. Protracted reproduction in sunfish: the temporal dimension in fish recruitment revisited. Ecological Applications 12: 194-205.

Gotceitas V, Puvanendran V, Leader LL, Brown JA. 1996. An experimental investigation of the 'match/mismatch' hypothesis using larval Atlantic cod. Marine Ecology Progress Series 130:29-37.

Graeb BDS, Mangan MT, Jolley JC, Wahl DH, Dettmers JM. 2006. Ontogenetic changes in prey preference and foraging ability of yellow perch: insights based on relative energetic return of prey. Transactions of the American Fisheries Society 135:1493-1498.

Hamley JM, Howley TP, Ponhani AL. 1983. Estimating larval abundances from plankton net catches in Lake Point Bay, Lake Erie, in 1971-78. Journal of Great Lakes Research 9:452-467.

Hart TF, Werner RG. 1987. Effects of prey density on growth and survival of white sucker, Catostomus commersoni, and pumpkinseed, Lepomis gibbosus, larvae. Environmental Biology of Fishes 18:41-50. 
Henderson BA. 1985. Factors affecting growth and recruitment of yellow perch, Perca flavescens Mitchill, in South Bay, Lake Huron. Journal of Fish Biology 26: 449-458.

Hjort J. 1914. Fluctuations in the great fisheries of northern Europe viewed in the light of biological research. Rapports et Proces-Verbaux des Re'unions Conseil International pour l'Exploration de la Mer 20:1-228.

Holland-Bartels LE, Littlejohn SK, Huston ML. 1990. A guide to larval fishes of the Upper Mississippi River. LaCrosse, Wisconsin: U.S. Fish and Wildlife Service, National Fisheries Research Center.

Houde ED. 1987. Fish early life dynamics and recruitment variability. Pages 17-29 in Hoyt RD, editor. Proceedings of the 10th Annual Larval Fish Conference. Bethesda, Maryland: American Fisheries Society.

Houde ED. 1994. Differences between marine and freshwater fish larvae: implications for recruitment. ICES Journal of Marine Science 51:91-97.

Houde ED. 2008. Emerging from Hjort's shadow. Journal of Northwest Atlantic Fishery Science 41:53-70.

Isermann DA, Hanchin PA, Willis DW. 2002. Comparison of two mesh sizes for collecting larval yellow perch in surface trawls. North American Journal of Fisheries Management 22:585-589.

Isermann DA, Willis DW. 2008. Emergence of larval yellow perch, Perca flavescens, in South Dakota lakes: potential implications for recruitment. Fisheries Management and Ecology 15:259-271.

Isermann DA, Willis DW, Blackwell BG, Lucchesi DL. 2007. Yellow perch in South Dakota: population variability and the predicted effects of creel limit reductions and minimum length limits. North American Journal of Fisheries Management 27:918-931.

Jackson JR, Noble RL. 2000. Relationships between annual variations in reservoir conditions and age-0 largemouth bass year-class strength. Transactions of the American Fisheries Society 129:699-715.

Jansen AC. 2008. Interannual variation in larval yellow perch abundance in eastern South Dakota glacial lakes and relation to sympatric walleye populations. Master's thesis. Brookings: South Dakota State University.

Jansen AC, Graeb BDS, Willis DW. 2009. Effect of a simulated cold-front on hatching success of yellow perch eggs. Journal of Freshwater Ecology 24:651655.

Johnson DL. 2000. Preliminary examination of the match-mismatch hypothesis and recruitment variability of yellowtail flounder, Limanda ferruginea. Fishery Bulletin 98:854-863.

Jolley JC. 2009. Recruitment of bluegill and yellow perch in Nebraska Sandhills lakes: integrating multiple life stages. Doctoral dissertation. Brookings: South Dakota State University.

Keast A. 1985. The piscivore feeding guild of fishes in small freshwater ecosystems. Environmental Biology of Fishes 12:119-129.
Lucchesi DO. 1991. Investigation of yellow perch population dynamics in eastern South Dakota lakes. Pierre, South Dakota: South Dakota Department of Game, Fish, and Parks. Fisheries Completion Report 92-1.

Ludsin SA, DeVries DR. 1997. First-year recruitment of largemouth bass: the interdependency of early life stages. Ecological Applications 7:1024-1038.

Marr JC. 1956. The "critical period" in the early life history of marine fishes. Extrait du Journal Du Conseil International Pour L'Exploration De La Mer 21:160170.

May RC. 1974. Larval mortality in marine fishes and the critical period concept. Pages 1-19 in Blaxter JHS, editor. The early life history of fish. New York: Springer-Verlag.

McCarraher DB. 1977. Nebraska's Sandhill lakes. Lincoln, Nebraska: Nebraska Game and Parks Commission.

Mertz G, Myers RA. 1994. Match/mismatch predictions of spawning duration versus recruitment variability. Fisheries Oceanography 3:236-245.

Miller TJ, Crowder LB, Rice JA, Marschall EA. 1988. Larval size and recruitment mechanisms in fishes: toward a conceptual framework. Canadian Journal of Fisheries and Aquatic Sciences 45:1657-1670.

Mills EL, Confer JL, Ready RC. 1984. Prey selection by young yellow perch: the influence of capture success, visual acuity, and prey choice. Transactions of the American Fisheries Society 113:579-587.

Mills EL, Forney JL. 1981. Energetics, food consumption, and growth of young yellow perch in Oneida Lake, New York. Transactions of the American Fisheries Society 110:479-488.

Mittelbach GG. 1981. Foraging efficiency and body size: a study of optimal diet and habitat use by bluegills. Ecology 62:1370-1386.

Partridge DG, DeVries DR. 1999. Regulation of growth and mortality in larval bluegills: implications for juvenile recruitment. Transactions of the American Fisheries Society 128:625-638.

Paukert CP, Willis DW, Gabelhouse DW. 2002a. Effect and acceptance of bluegill length limits in Nebraska natural lakes. North American Journal of Fisheries Management 22:1306-1313.

Paukert CP, Willis DW, Klammer JA. 2002b. Effects of predation and environment on quality of yellow perch and bluegill populations in Nebraska Sandhill lakes. North American Journal of Fisheries Management 22: 86-95.

Pepin P. 2004. Early life history studies of prey-predator interactions: quantifying the stochastic individual responses to environmental variability. Canadian Journal of Fisheries and Aquatic Sciences 61:659-671.

Pope KL, Willis DW. 1998. Early life history and recruitment of black crappie (Pomoxis nigromaculatus) in two South Dakota Waters. Ecology of Freshwater Fish 7:56-68.

Prout MW, Mills EL, Forney JL. 1990. Diet, growth, and potential competitive interactions between age-0 
white perch and yellow perch in Oneida Lake, New York. Transactions of the American Fisheries Society 119:966-975.

Rabeni CF. 1996. Invertebrates. Pages 335-351 in Murphy BR, Willis DW, editors. Fisheries techniques. 2nd edition. Bethesda, Maryland: American Fisheries Society Bethesda.

Rice JA, Crowder LB, Holey ME. 1987. Exploration of mechanisms regulating larval survival in Lake Michigan bloater: a recruitment analysis based on characteristics of individual larvae. Transactions of the American Fisheries Society 116:703-718.

Santucci VJ Jr, Wahl DH. 2003. The effects of growth, predation, and first-winter mortality on recruitment of bluegill cohorts. Transactions of the American Fisheries Society 132:346-360.

Schael DM, Rudstam LG, Post JR. 1991. Gape limitation and prey selection in larval yellow perch (Perca flavescens), freshwater drum (Aplodinotus grunniens), and black crappie (Pomoxis nigromaculatus). Canadian Journal of Fisheries Aquatic Sciences 48:1919-1925.

Sommer U, Gliwicz ZM, Lampert W, Duncan A. 1986. The PEG-model of seasonal succession of planktonic events in fresh waters. Archiv für Hydrobiologie 106: 433-471.

Taylor WD, Fricker H-J, Lean DRS. 1987. Zooplankton seasonal succession in Lake Ontario at northshore, midlake, and southshore stations in 1982, and a comparison with 1970. Canadian Journal of Fisheries and Aquatic Sciences 44:2178-2184.
Toetz DW. 1966. Change from endogenous to exogenous sources of energy in bluegill sunfish larvae. Investigations of Indiana Lakes and Streams 7:115-146.

Wahl CM, Mills EL, McFarland WM, DeGisi JS. 1993. Ontogenetic changes in prey selection and visual acuity of the yellow perch, Perca flavescens. Canadian Journal of Fisheries and Aquatic Sciences 50:743-749.

Weber JJ, Les BL. 1982. Spawning and early life history of yellow perch in the Lake Winnebago system. Madison, Wisconsin: Wisconsin Department of Natural Resources. Technical Bulletin Number 130.

Welker MT, Pierce CL, Wahl DH. 1994. Growth and survival of larval fishes: roles of competition and zooplankton abundance. Transactions of the American Fisheries Society 123:703-717.

Werner EE, Hall DJ. 1988. Ontogenetic habitat shifts in bluegills: the foraging rate-predation risk trade-off. Ecology 69:1352-1366.

Werner RG. 1969. Ecology of limnetic bluegill (Lepomis macrochirus) fry in Crane Lake, Indiana. American Midland Naturalist 81:164-181.

Whiteside MC, Swindoll CM, Doolittle WL. 1985. Factors affecting the early life history of yellow perch, Perca flavescens. Environmental Biology of Fishes 12:47-56.

Winemiller KO, Rose KA. 1993. Why do most fish produce so many tiny offspring? The American Naturalist 142: 585-603.

Young KV, Dower JF, Pepin P. 2009. A hierarchical analysis of the spatial distribution of larval fish prey. Journal of Plankton Research 31:687-700. 